\title{
Chinese Translation Strategies of Japanese Mental Cultural Vocabulary from the Perspective of Adaptation Theory
}

\author{
Huiyu Jiao* \\ College of Foreign Languages, Northeast Forestry University, Harbin 150000, China \\ *Corresponding author: Huiyu Jiao, 18345860084@163.com
}

\begin{abstract}
Mental cultural vocabulary is a type of cultural vocabulary. This kind of vocabulary is a valuable carrier of the spiritual material culture of a nation or a country. The translation of these words can directly reflect the differences between different cultures, which plays an important role in cross-cultural communication. The translation strategies in dealing with mental cultural vocabulary translation is emphasized as it is a difficulty faced in translation practice. Based on the adaptation theory, this study analyzes the examples and translation from the perspective of dynamic adaptation as well as explains the adaptation at all levels in translation practice.
\end{abstract}

Keywords: Adaptation theory; Pragmatics; Mental cultural vocabulary; Translation strategy

Publication date: October 2021; Online publication: October 29, 2021

\section{Introduction}

From the 1950 s to the 1990 s, the theory of translation studies has occupied a leading position in translation studies at home and abroad. However, the conversion between linguistic signs is not completely formulaic and structured. In addition to considering the objective factors of code conversion, subjective factors such as the expression of the author and the feelings of the target readers should also be considered. Pragmatics, as a discipline that studies the relationship between language use and language users, can provide a perspective on the meaning of pragmatic communication for translation studies. The adaptation theory from the perspective of pragmatics, put forward by Jef Verschueren, states that the use of language is a process of constantly making choices to adapt to the needs of communication under different levels of consciousness ${ }^{[1]}$. From the perspective of this dynamic, non-linguistic internal factor, this research explores the Chinese translation strategies of mental cultural vocabulary, which carries more spiritual and cultural connotations in Japanese, in order to bring useful thinking to Japanese learners and promote further exchanges in the Chinese-Japanese culture.

\section{A review of adaptation theory}

\subsection{Important concepts in adaptation theory}

Adaptation theory was originally derived from the theory of biological evolution, which refers to a behavior in which organisms gradually evolve as they continue to adapt to new environments. In 1985, Jef Verschueren, a well-known Belgian linguist and the Secretary-General of the International Pragmatics Society, introduced adaptation to pragmatics for the first time in Understanding Pragmatics, forming a theory based on the perspective of pragmatics. 
The important concepts put forward by the theory include "making a choice" as well as "variability, synergy, and compliance of language." Verschueren mentioned that the use of language is a discontinuous process of language selection. This choice may be either conscious or unconscious, and it happens at every level of language. The speaker chooses the language, and at the same time, the speaker will also choose to use a certain strategy ${ }^{[1]}$. The reason why humans are able to make choices when using language is because language has variability, negotiability, and adaptability. Among them, variability refers to a series of options for language; synergy means that the choice of language is not made mechanically or strictly in accordance with the form-function relationship but is done on the basis of highly flexible principles and strategies; compliance refers to the user's ability to choose flexibly to meet the needs of communication. Among these three characteristics, the core of language use is compliance.

\subsection{Adaptation theory in translation}

From the concept of adaptation theory, it can be appreciated that the problem it discusses is in the process of communication, where interacting parties need to constantly choose and adapt when using a certain language, so as to achieve the purpose of the transaction through communication. Translation, as a communicative activity between author-translator-reader, exists within the scope of interpretation and guidance by the adaptation theory ${ }^{[2]}$. The core of translation is the communication and exchange between diverse cultures. When translators perform translation activities, they are in a dynamic process of consciously or unconsciously making choices continuously. Therefore, the adaptation theory has a strong guiding significance for translation studies. The translation model under the guidance of the introduction theory goes as such: clarifying the purpose of translation $\rightarrow$ interpret the source text $\rightarrow$ choose the level of adaptation $\rightarrow$ choose translation strategies, techniques, and methods $\rightarrow$ achieve adaptation and complete translation communication. Adaptation theory has given new enlightenment and research directions to translation studies, from narrow and simple code switching and translation techniques to focusing on differences in non-linguistic factors among different cultures. The three characteristics of language in the adaptation theory indicate that translators do not make choices arbitrarily when translating. The choices made must not only meet the translation purpose, but also restricted by various aspects.

\section{Concept and classification of cultural vocabulary}

Cultural vocabulary is a vocabulary with a certain cultural load. This kind of vocabulary is a precious carrier of the spiritual material culture of a nation or a country. It is also the core and essence of the entire vocabulary system ${ }^{[3]}$. Such words are subject to cultural constraints, from which they can reflect cultural differences between different countries ${ }^{[4]}$. Domestic and foreign scholars have different perspectives on cultural vocabulary. The famous British translator, Newmark, claimed that cultural vocabulary is unique and cannot be literally translated. Such vocabulary is a cultural vacancy word that causes translation problems ${ }^{[5]}$. A domestic scholar, Chang Jingyu, stated, "Cultural vocabulary refers to the vocabulary of a specific cultural category. It is a direct or indirect reflection of national culture in language vocabulary ${ }^{[6]}$." Based on the above concepts, the relationship between cultural vocabulary and other ordinary vocabulary is not separated. Cultural vocabulary has linguistic meaning, but at the same time, it also has cultural significance.

Since culture is a complex concept, scholars at home and abroad have always had different opinions on the classification of cultural vocabulary. Foreign scholars such as Nida and Newmark, as well as domestic scholars such as Wang Dechun, Meng Zimin, and Wang Guoan have all classified them from different levels. However, the classification of Zhang Gaoxiang is clearer and easier to understand. Starting from the four-layer theory of cultural structure, he divided cultural vocabulary into four ${ }^{[7]}$. 
(1) Material cultural vocabulary.

Refers to the words that humans process and create various artifacts through nature. For example, in Japanese, “神社” (jinjya), “寿司” (sushi), “羽織” (haori), etc.

(2) Institutional cultural vocabulary.

Refers to the various norms, guidelines, and forms of organization established by human beings in social practice. For example, in Japanese, “天皇” (tenou), “年功序列” (nenkoujyoretu), “遣唐使” (kentoushi), etc.

(3) Behavioral cultural vocabulary.

Refers to words that reflect the customs and habits established by conventions. For example, in Japanese, “打辞儀” (ojigi), “盆踊り” (bonodori), “海の日” (uminohi), etc.

(4) Mental cultural vocabulary.

Refers to words that reflect people's values, aesthetic tastes, way of thinking, religious feelings, national characteristics, etc. This research studies such words and analyzes Chinese translation strategies in Japanese mental cultural vocabulary.

\section{Analysis of Chinese translation strategies in mental cultural vocabulary}

\subsection{Meaning and characteristics of mental cultural vocabulary}

The mental cultural vocabulary is the core aspect of social mass psychology and ideology culture in languages ${ }^{[3]}$. Such vocabulary usually condenses extremely rich national wisdom as well as national historical and cultural information in very few words. Therefore, mental cultural vocabulary has the characteristics of few words in form but with large amount of national cultural information in content. It includes terms such as “唱高调,”“穿小鞋,”“灯下黑,”“老油条,”“仁义道德, “四书五经,”“阴阳五行,” etc. in Chinese and “俳句” (haiku), “一期一会” (ichigoichie), “以心伝心” (ishindenshin), “猪突猛進” (cyototumoushin), “高嶺の花” (takanenohana), “月夜に提灯” (tukiyonicyouchin), “油を売る” (aburawouru), etc. in Japanese. This section will begin by discussing Japanese three-character idioms, fourcharacter idioms, and locution, and then analyze the choices and adaptations when translating mental cultural vocabulary.

\subsection{Three-character idiom}

Three-character idioms mostly come from the general public. They have a strong tendency to be used verbally as they belong to a type of vocabulary established by the general public. Due to the long history of exchanges between China and Japan, some of the three-character idioms have formed common expressions and connotations, which can correspond to each other, such as “走馬燈” (soumatou), “風馬 牛” (fuubagyuu), “登竜門” (touryuumon), and so on. These words are basically the same in the two languages, and they have the same meaning. When translating into Chinese, literal translation can be used without affecting the readers. Some three-character idioms can only form a partial correspondence, such as “茶飯事” (sahanji), “一家言” (ikkagen), “美人局” (tutumotase), etc. It is not necessary to adapt to the structural factor when translating; the number of words can be increased or decreased appropriately. Some of the three-character idioms have been created by the Japanese themselves, and usually, Chinese readers are not able to understand such words literally. 
Table 1. Examples of three-character idioms and their meanings

\begin{tabular}{|c|c|c|}
\hline Japanese & Original meaning and allusion & Chinese translation \\
\hline $\begin{array}{c}\text { 天邪鬼 } \\
\text { (amanojyaku) }\end{array}$ & $\begin{array}{l}\text { 日本民间故事《瓜子姑娘》中出现的恶鬼; 或 } \\
\text { 者指佛教中四大天王踩在脚下的异教恶鬼。 } \\
\text { (The evil spirit that appeared in the Japanese folk } \\
\text { tale, Melon Seed Girl or the pagan evil spirit that } \\
\text { the four kings in Buddhism stepped on.) }\end{array}$ & $\begin{array}{l}\text { 喜欢唱反调的人; 脾气别扭的人; 固执已见的人; } \\
\text { 乘僻的人 } \\
\text { (A person who likes to distort the tune; a person who } \\
\text { has an awkward temper; a stubborn person; a perverse } \\
\text { person) }\end{array}$ \\
\hline $\begin{array}{c}\text { 八百長 } \\
\text { (yaocyou) }\end{array}$ & $\begin{array}{l}\text { 日本旧时有一个叫八百屋的长兵卫（简称八百 } \\
\text { 长）在围棋比赛中故意输给棋力弱的对手的故 } \\
\text { 事。 } \\
\text { (In ancient Japan, there is a story about Yaocyo } \\
\text { Chobee (or Yaocyo in short) who deliberately } \\
\text { loses to a weak opponent in a Go game.) }\end{array}$ & $\begin{array}{l}\text { 实际上商量好胜负的假比赛; 骗局; 预先合谋做勾 } \\
\text { 当 } \\
\text { (Fake matches that actually negotiate the outcome; } \\
\text { scam; pre-conspiracy) }\end{array}$ \\
\hline $\begin{array}{c}\text { 天王山 } \\
\text { (tennnouzann) }\end{array}$ & $\begin{array}{l}\text { 天王山是位于京都府南部海拔 } 270 \mathrm{~m} \text { 的山。在 } \\
1582 \text { 年的山崎之战中, 首先占领天王山的丰臣 } \\
\text { 秀吉军打败了明智光秀军。 } \\
\text { (Tennozan is a mountain located } 270 \text { meters above } \\
\text { sea level in the southern part of Kyoto prefecture. } \\
\text { In the Battle of Yamazaki in 1582, the Toyotomi } \\
\text { Hideyoshi Army, who first occupied Mount } \\
\text { Tenno, defeated the Akechi Mitsuhide Army.) }\end{array}$ & $\begin{array}{l}\text { 决定胜负的重要情况或时刻; 胜负的分水岭。 } \\
\text { (An important situation or moment that determines the } \\
\text { victory or defeat; the watershed of victory or defeat.) }\end{array}$ \\
\hline
\end{tabular}

Table 1 shows that there is more than one translation for this kind of three-character idioms. In order to translate these words well, translators need to master the source allusions or original meanings of those words; second, they need to closely consider the context and choose the most suitable one from the many translation options. The original text of the analysis is from The Dedication of Suspect $X$ by the famous Japanese suspense novelist, Keigo Higashino, while the translation is by a translator, Liu Ziqian.

\section{Example 1}

ST:「事件直後に...僕は久しぶりに好敵手と再会できたことで、ちょっと有頂天にさえなっ ていた」

TT: 命案刚发生时......能和睽违已久的劲敌重逢, 我甚至有点乐昏了头。

(When the murder happened...I felt a little dizzy to be able to reunite with my long-lost enemy.)

\section{Example 2}

ST: 石神が見ていると目が合った。気まずそうにするかと思ったが、森岡は大袈乷に顔をし かめ、両手でメを作った。とても解けない、といいたいようだ。

$\mathrm{TT}$ : 石神朝他一看, 当下四目相对。本以为森冈会觉得尴尬, 没想到他夸张地皱起眉头, 双手 比出一个大叉，好像想说：我其实不会作答。

(Ishigami looked at him, and his eyes met Morioka. He thought Morioka would feel embarrassed, but he did not expect him to frown exaggeratedly, making a cross with his hands, as if he wanted to say: I do not know how to answer actually.) 
In Example 1, “有頂天” (ucyoutenn) was originally used as a Buddhist term, referring to the uppermost sky in the Three Realms. Its original meaning has been extended to "ecstatic and happily forgetting oneself." The original text depicts a dialogue between the characters. The translator is more or less aware of this. Instead of choosing a more literal translation - "ecstatic," the translator chose a more colloquial term "le fainted." The translation method reflects the translator's salience in translation.

In Example 2, “大袈乷” (oogesa) originally refers to Buddha's robes and also the large robes of the Japanese sword. With the passage of time, it gradually deviated from the original meaning and evolved into other meanings - "exaggeration," "making a fuss," or "exaggerating more than reality." This term is used as an adjective verb in the original text to describe the degree of frowning. The translator has chosen the concise word of "exaggeration," which does not add to the reading burden of the original text with more sentences.

\subsection{Four-character idiom}

Most of the four-character idioms in Japanese are introduced by the Chinese, but with the development of the language, there are still Japanese words that imitate the form of Chinese words. Wang Ling classified Japanese four-character idioms as follows: (1) four-character idioms derived from Chinese classics; (2) four-character idioms derived from Buddhist culture; (3) four-character idiom derived from Japanese customs (Table 2) ${ }^{[8]}$.

Table 2. Classification of four-character idioms

\begin{tabular}{|c|c|c|}
\hline Japanese & Origin & Chinese translation \\
\hline $\begin{array}{c}\text { 左右他言 } \\
\text { (sayuutagon) }\end{array}$ & $\begin{array}{l}\text { 源于中国古典自创的四字成语。出自《孟子.梁惠 } \\
\text { 王下》, “......王顾左右而言他”。指离开话题, } \\
\text { 回避难以答复的问题。 } \\
\text { (Originated from Chinese classics. From Mencius: } \\
\text { Under King Lianghui, “......王顾左右而言他” } \\
\text { refers to evading the topic and avoiding difficult } \\
\text { questions.) }\end{array}$ & $\begin{array}{l}\text { 顾左右而言他; 左右言他 } \\
\text { (Evade the question by changing the subject) }\end{array}$ \\
\hline $\begin{array}{c}\text { 三人文殊 } \\
\text { (sanninmonjyu) }\end{array}$ & $\begin{array}{l}\text { 源于佛教文化自创的四字成语。“文殊”是佛教四 } \\
\text { 大菩萨之一的文殊菩萨。是浐语 “三人寄れば文 } \\
\text { 殊の知恵” 的缩略语。 } \\
\text { (Originated from the Buddhist culture. “Manjushri” } \\
\text { was one of the four Bodhisattvas. It is an } \\
\text { abbreviation of the proverb “三人寄れば文殊の知 } \\
\text { 恵.”) }\end{array}$ & $\begin{array}{l}\text { 三个臭皮匠顶个诸葛亮; 人多智广 } \\
\text { (Two heads are better than one; there would } \\
\text { be more ideas with more people) }\end{array}$ \\
\hline $\begin{array}{l}\text { 一期一会 } \\
\text { (ichigoichie) }\end{array}$ & $\begin{array}{l}\text { 源于日本风土人情自创的四字成语。出自日本茶 } \\
\text { 道大师所著《山上宗二记》, 是对日本茶道精神 } \\
\text { 的一种诠释。 } \\
\text { (Originated from Japanese customs. It comes from } \\
\text { “山上宗二记,” written by a Japanese tea ceremony } \\
\text { master, which is an interpretation of the spirit of } \\
\text { Japanese tea ceremony.) }\end{array}$ & $\begin{array}{l}\text { 机会难得; 一生仅此一会的茶道精神 } \\
\text { (Opportunities are rare and far between; the } \\
\text { one and only encounter for a lifetime) }\end{array}$ \\
\hline
\end{tabular}


First of all, several Japanese self-created four-character idioms derived from Chinese classics. After localized modifications or deletions, they become self-created idioms, such as “遠慮近憂” (enryokinyuu), “悪事千里” (akujisenri), “快刀乱麻” (kaitouranma), etc. Chinese native speakers can generally understand the meaning of those words literally.

Secondly, as the Buddhist culture was introduced to ancient China from ancient India, and then to Japan via the Korean Peninsula, the Buddhist cultures in both China and Japan have a long history. These words can form a certain degree of correspondence, but native Chinese speakers may not understand the literal meaning of those words.

\section{Example 3}

ST: 入院、手術、看病一—まるでベルトコンベアに載せられているみたいだった。無我夢中 で時間が過ぎで、そうして逝ってしまった。

$\mathrm{TT}$ : 住院, 开刀, 照顾病人一一简直就像被放在自动传送带上一样。时间就这么迷迷糊糊地过 去了。

(To be hospitalized, operated on, and cared for as a patient - it is like being placed on an automatic conveyor belt. Time just passes by in such a daze.)

“無我夢中” (mugamucyuu) in Example 3 is a four-character idiom derived from the Buddhist culture. “無我” is one of the basic teachings of Buddhism, in which all existence is born from karma and there is no fixed entity. The word “夢中” means “to be enthusiastic” or “to be enchanted.” “無我夢中” emphasizes the state of being absorbed and forgetting oneself. The original text is about a person's illness, hospitalization, surgery, and death, as well as how time flies by inexorably. Here, if “無我夢中” is simply assumed as "forgetfulness," "enthusiasm," or "fascination," it does not seem to complement with the context. In this case, the translator has done a good job in linking the context and making contextual relationships; thus, the translation of this term is natural and appropriate.

Finally, compared with the above two idioms, four-character idioms derived from Japanese customs contain more national history, culture, and Japanese values, such as “手前味噌” (temaemiso), which is derived from Japanese food culture; “一人相撲” (hitorizumou), from Japanese sports culture; well-known ancient Japanese stories which include “白河夜船” (shirakawayofune), “小春日和” (koharubiyori), and “電光朝露” (dennkoucyouro) are from the meticulous experience of nature. All these terms contain rich cultural meaning. However, such words do not have a fixed translation. It is necessary to fully understand the context, and then translate in consideration of the full context. This requires translators to have understanding of the meaning, origin, and even emotional color behind such words and choose the adaptation that meets the purpose of translation.

\subsection{Locution}

Locution is an expression with a relatively fixed structure and a specific meaning. This form of fixed collocation contains the Japanese way of thinking in regard to the material and spiritual world. Sakada Yukiko mentioned, "Locution appears as fixed phrases or sentences, and the entire phrase or sentence expresses a specific semantic language form. For example, ‘腹が立つ' (haraga tatu) means 'angry' (anger) [9]." This form of fixed collocation contains the Japanese way of thinking in regard to the material and spiritual world. For example, in Japan, sea bream is regarded as the "king of fish" and is one of the delicacies at Japanese wedding banquets. In view of its pronunciation, which rhymes with “めでたい” (medetai), it has been given a positive cultural sense, reflecting "good luck" or "celebration," by the Japanese. Table 3 shows examples of Japanese locution with the word "bream." 
Table 3. Japanese locution with the word "bream"

\begin{tabular}{cl}
\hline Japanese & \multicolumn{1}{c}{ Chinese translation } \\
\hline 海老で鯛を釣る & 一本万利; 事半功倍 \\
(ebide taiwo turu) & (Gain enormous profits out of a small investment; achieve maximum results with little effort) \\
鯛の尾より鰯の頭 & 宁做鸡头不做凤尾 \\
(taino oyori iwashino atama) & (I would like to be a big fish in a small pond rather than a small fish in a big pond) \\
\hline
\end{tabular}

The literal translation of “海老で鯛を釣る” is “fishing for sea bream with small shrimps.” It is a metaphor that a lot of benefits can be obtained with very little labor or goods. In the Chinese vocabulary system, "small shrimps" reflect "small" or "worthless" by native speakers; they do not have the same understanding of "sea bream" as the Japanese. If it is literally translated into Chinese, it would be difficult for native Chinese speakers to understand the meaning of this locution due to the differences in the perception of sea bream between the Chinese and Japanese. Another example is the literal translation of “鯛の尾より鮙の頭” into Chinese: “Being the tail of a sea bream is better than the head of a sardine.” From the Chinese point of view, the meaning is unclear. However, when native Chinese speakers understand the cultural significance of sea bream and sardines in the Japanese language, they would be able to correlate with “宁做鸡头, 不做凤尾” (I would like to be a big fish in a small pond rather than a small fish in a big pond). This is also one of the cultural adaptation methods used by translators to facilitate target language readers in understanding the original expression.

\section{Example 4}

ST: 草薙は先ほどから目の前のチェス盤を二十分以上にらんでいるが、どう考えても打開策 はキングの逃げ道はなく、窮鼠猫を嚙むとばかりにがむしゃらに攻撃するすべもない。 TT: 草薙从刚才就对着眼前的棋盘瞪了二十分钟以上, 还是想不出破解的对策。国王无路可逃, 虽然想狗急跳墙, 却连胡乱攻击的对策也没有。

(Kusanagi has been staring at the chessboard in front of him for more than 20 minutes but still could not think of a solution. The king had nowhere to escape. Although worm wanted to turn, he did not even have a countermeasure to attack indiscriminately.)

\section{Example 5}

$\mathrm{ST}:\lceil\ldots$ 君が共犯者なら、君のアリバイについても調べれば、君たちの牙城を崩せると思っ ている。」

TT: “......你若是共犯, 只要随便调查你的不在场, 他们以为就能瓦解你们的防御。”

(“... If you are an accomplice, just by investigating your absence, they think they can break your defense.")

In Example 4, “窮鼠猫を嚙む” comes from “穷鼠啃狸” (a cornered rat will bite a cat) in The Discourses of Salt and Iron (“盐铁论”). It refers to a mouse that is chased and has nowhere to escape. It is a metaphor that the weak are forced to be helpless, but they will fight back desperately against the strong. The text in the example describes the scene of Kusanagi playing chess with Yugawa. In order to set off Kusanagi's embarrassed state, the author used the locution “窮鼠猫を嚙む” to demonstrate the intense scene in a vivid manner. “狗急跳墙” (even a worm will turn) reflects the embarrassment of the character who wishes to fight back. This allows the readers to experience the state of the character in the book. 
In Example 5, “牙城,” which is derived from the Book of Tang Dynasty (“唐书”), refers to the city with the tooth flag (the general's flag) positioned. It gradually evolves in reference to the enemy's headquarters or the center of a certain force. The characters in the book are divided into three main factions: the police faction, the Ishigami and Hanaoka faction, as well as the Yugawa faction. Among them, Yugawa is a neutral faction, but the police and the Ishigami and Hanaoka factions have formed a hostile state. It has been translated as “瓦解你们的防御” (disrupting your defense), which adapts to the language structure so that the translation can truly reflect the author's expressive intention and achieved the effect of faithfulness to the original text.

Since locutions generally occur in relatively fixed forms, translators should not only grasp the linguistic meaning of such words, but also understand their inherent cultural meanings, and make adaptations to nonlinguistic factors, so as to be able to fully and accurately target the purpose. Language readers convey the cultural information it carries. If there are differences or gaps between the cultural meanings of the source language and the target language vocabularies, it is necessary to choose expressions with the same or similar cultural meaning in the target language to reduce cultural differences and fill in the cultural gaps, so that the target language readers would be able to understand the meanings ${ }^{[8]}$.

\section{Conclusion}

The language and culture of China and Japan have a long history and grand content. Chinese characters have made the language link between the two countries closer. With the continuous development of the history and culture of the two countries, the same Chinese characters have derived different cultural colors in the two nations. Mental cultural vocabulary has always been the focus and difficulty in Japanese-Chinese translations. It is the same with translations of any two languages. The adaptation theory does not only guide the translation practice at the micro level of language structure, but also from a macro perspective, integrating the political, economic, historical, geographical, and other factors of different cultures to explain and clarify the particularity as well as complexity of translations.

Through the induction and analysis of Japanese mental cultural vocabulary, this research draws the following conclusion: when translating Japanese mental cultural vocabulary, domesticating strategies result in a better translation effect. Since such words do not only have linguistic meanings, but also nationalspecific spiritual and cultural meanings with abundant national customs and national wisdom, if a translator uses the foreignizing strategy, it is necessary to add certain comments after the translation, which would greatly affect the reading experience and fluency of the target language readers. The purpose of translation should be in a way whereby target language readers are able to understand the meaning of the translated term similar to that of the source language readers. Therefore, when translating such terms, translators should first clarify the translation purpose. It should be focused on adapting to the physical, social, and psychological non-verbal elements of the target language readers. Choosing expressions in the target language that can narrow or fill the cultural gaps would help target language readers to feel closer to the source language readers.

\section{Disclosure statement}

The author declares that there is no conflict of interest.

\section{References}

[1] Verschueren J, 1999, Understanding Pragmatics, Arnold, London.

[2] Ge L, 2002, The Enlightenment of Adaptation Theory to Translation Studies - Also on Pragmatic Translation Standards. Foreign Languages Journal, (03): 7-11. 
[3] Fu C, 2011, A Survey of Cultural Words. Journal of North China University of Science and Technology (Social Science Edition), 11(03): 109-112.

[4] Samova LA, Porter RE, Stefani LA, 1998, Communication between Cultures, Wadsworth Publishing Company, Belmont.

[5] Newmark P, 2001, A Textbook of Translation, Shanghai Foreign Language Education Press, Shanghai.

[6] Chang J, 1995, Chinese Vocabulary and Culture, Peking University Press, Beijing.

[7] Zhang G, 2003, On Cultural Words in Teaching Chinese as a Foreign Language. Journal of Yunnan Normal University, (03): 61-65.

[8] Wang L, 2014, A Classification of Japanese-Made Four-Character Idioms and Analysis of Their Cultural Elements. Foreign Language Research in Northeast Asia, 2(02): 27-32.

[9] Yukiko S, 1982, Idiomatic Expression. Japanese Education Encyclopedia, Taisyukansyoten, Tokyo. 